American Journal of Applied Sciences 7 (10): 1300-1304, 2010

ISSN 1546-9239

(C) 2010 Science Publications

\title{
Drying Characteristics of Chili Using Continuous Fluidized-Bed Dryer
}

\author{
${ }^{1}$ Suparerk Charmongkolpradit, ${ }^{1}$ Kittichai Triratanasirichai and ${ }^{2}$ Narong Srihajong \\ ${ }^{1}$ Department of Mechanical Engineering, Faculty of Engineering, \\ Khon Kaen University, 123 Mittraparb Road, Muang District, Khon Kaen, 40002, Thailand \\ ${ }^{2}$ Department of Mechanical Engineering, Faculty of Engineering, \\ Rajamangala University of Technology Isan, Khon Kaen Campus, Khon Kaen, 40000, Thailand
}

\begin{abstract}
Problem statement: The objective of this study was to obtain the dying characteristics of the Jinda chili, a commonly grown variety in the Northeatern of Thailand, using the continuous fluidizedbed dryer in reducing moisture content of dried chili up to $13 \%$ wet basis as comparable to the dried chili in the market and to investigate the effect of drying temperature and drying air velocity. Approach: Drying characteristics was to study under varying conditions of drying temperature (50, $60,70,80,90$ and $\left.100^{\circ} \mathrm{C}\right)$ and drying air velocity $\left(4,5\right.$ and $\left.6 \mathrm{~m} \mathrm{sec}^{-1}\right)$. Results: The drying time decreased within the increasing of drying temperature and drying air velocity. Drying air velocity affected the drift and continuously moves of chili particle outward from dryer chamber under continuous fluidized-bed technique. The decreasing of moisture content effected with increasing of a compound capsaicin of dried chili compare to fresh chili. The diffusion coefficient of moisture content increased with increasing all drying temperature and drying air velocity. Conclusion: Drying temperature was the significant factor of the chili moisture content reduction. Drying air velocity affected the move of chili outward from chamber under the continuous fluidized bed drying process.
\end{abstract}

Key words: Jinda chili, fluidized-bed, Capsicum

\section{INTRODUCTION}

Chilli is known by different names in different parts of the world. The genus Capsicum which is commonly known as "red Chile", "chili pepper", "hot red pepper", "tobasco", "paprika", and "cayenne", (De, 2003). Chili peppers (Capsicum spp.) are appreciated for their pungency, taste and aroma as food additive, pigment and for their physiological and pharmaceutical uses (Cisneros-Pineda et al., 2007). Hot chili pepper is a common spice in Thai cuisine and it is widely consumed as a food additive throughout the world, particularly in South East Asia and Latin-American countries (Laohavechvanich et al., 2006). As, ripe chilies usually have initial moisture content as high as $300-400 \%(\mathrm{db})$, this has to be reduced to $8-11 \%(\mathrm{db})$ for the safe storage (Satyanarayana and Vengaiah, 2010). Traditionally, fresh chilies are preserved by drying immediately after harvest under the sun without any special treatment (Kaleemullah and Kailappan, 2005). Haddad (2009) studied the mathematical method for defining the dimensions of drying machine to obtain optimum productivity with lowest power energy consumption and basic theoretical backgrounds of the engineering design procedure of a drying plant. Shafri and Ezzat (2009) studied on quantitative performance of spectral indices in large scale plant health analysis. Accordingly, procurement of machineries and drying apparatus are burdens to some operators (Tasirin et al., 2006).

Chili is one of economic plants and involve with Thai society, especially with its daily cooking. A very unique characteristic of chili is the spiciness which comes from the chemical substance called Capsaicin. Chili can be grown all year round. However, the good periods of growing chili in the Northeastern of Thailand are in rainy season and winter. During those periods there will be a problem of overflow with chili in the market. Dried chili was introduced to be controlled the quantity and the stability of price of during that period. Preservation of chili for other period is also the other way to keep the price. The conventional method to preserve the chili is to dried up under the sun by spreading the chili in the large open area. The duration needed depends on the quality of sunlight, temperature and air humidity. One of the problems by this technique

Corresponding Author: Suparerk Charmongkolpradit, Department of Mechanical Engineering, Faculty of Engineering, Khon Kaen University, 123 Mittraparb Road, Muang District, Khon Kaen, 40002, Thailand Tel: +66 43202845 Fax. +6643202849 
is that the level of moisture content of dried chili was not the same and other problems are caused by weather, fungus, which decrease the length of time that can be kept. Moreover, there might also be a contamination in the chili. The main advantage of fluidized-bed dryer is the high transfer rate for heat and mass between gas and solid that ensure a rapid and uniform drying. Apart from this, heat transfer rate between the fluidized layer and immersed object is high. Therefore, only a small area is needed for heat transfer (Tasirin et al., 2006). And technological innovation was adapted to protect crop might bring about significant benefits to farmers (Luce et al., 2006).

Also, this study focused on drying characteristic, the drying effective diffusivities and activation energy on drying process of capsicum using continuous fluidized-bed dryer in order to investigate physical characteristic of chili after drying, to consider the effect of drying temperature and drying air velocity, to suggest drying method using suitable condition which was concerned with the quality of a product.

\section{MATERIALS AND METHODS}

Sample preparation: Since there are many kinds of chili, the researcher decided to use Jinda chili; a kind of chili which is largely sold in the Northeastern market of Thailand in both fresh and dried type. The clean chili would be processed in the Central Laboratory (Thailand) Ltd., Khon Kaen Branch, in order to specify the initial moisture content $72.98 \%$ on wet basis (Stephen and Emmanuel, 2009) and contained 0.07 of capsaicin quantity substance $\left(\mathrm{g} 100 \mathrm{~g}^{-1}\right)$ by HPLC based on AOAC (1995) 995.03 in house method, before the continuous fluidized bed drying was used in the experiment, where the chili's weighted $1000 \mathrm{~g}$ would be started.

Experiments set-up: Figure 1 showed a schematic diagram of a dryer, a continuous chili artificial dryer which consisted of its essential devices, heaters, drying chamber, instruments for measurement, centrifugal blower-3 horsepower motor driven and $1450 \mathrm{rpm}$ of revolution. The air flow rate was adjusted by the blower speed control which was reused again by the use of air circulation, delivering to the drying process. The heating system consisted of 8 electric sets with $1.5 \mathrm{~kW}$ heater placed inside the duct. The temperature in drying chamber was adjusted by the heater power control. The drying chamber was conducted from stainless steel sheets as rectangular tunnel with $1000 \mathrm{~cm}$ long, $30 \mathrm{~cm}$ wide and $50 \mathrm{~cm}$ high. It was brought into this study that relied on the continuous fluidized bed dryer.

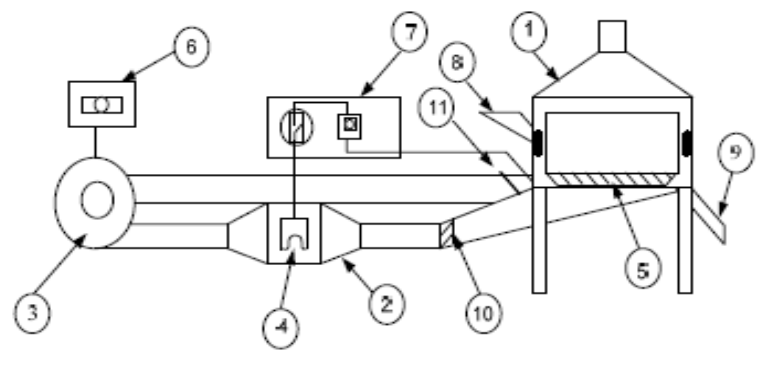

Fig. 1: Schematic of the dryer (1) Drying chamber; (2) Heater casing; (3) Blower; (4) Heater; (5) Trays; (6) Blower speed control; (7) Heater power control; (8) Inlet gate of products; (9) Outlet gate of products; (10) Air distributor plate; (11) Thermocouple sensor

In the measurement of temperature, $\mathrm{K}$ type thermocouples were used with manually controlled temperature (Shinko, MCD-130-R/E, Japan), with accuracy of $\pm 1^{\circ} \mathrm{C}$. The temperature recorded with a manually controlled 32-channel automatic digital thermometer (Hioki, 8422-51, Japan). The drying air velocity passing through the system was measured by a 0.8-12.0 $\mathrm{m} \mathrm{sec}^{-1}$ range anemometer mini vane (Digicon, DA-45, Japan) with accuracy of $0.01 \mathrm{~m} \mathrm{Sec}^{-1}$ and uncertainly of $\pm\left(2 \%+0.2 \quad \mathrm{~m} \quad \mathrm{sec}^{-1}\right)$. A thermohygrometer (Digicon, T-126TH-S, Japan) with accuracy of $0-100 \% \mathrm{RH}$ and uncertainly of $\pm 2.5 \% \mathrm{RH}$ (30-90RH). Moisture loss was recorded at intervals of 5 min during drying for determination of drying curves by a digital balance (Ohaus, Adventurer-ARC210 and USA) in the measurement range of 0-2100 $\mathrm{g}$ and readability of $0.01 \mathrm{~g}$.

Drying experiment was carried out at drying air temperature of $50,60,70,80,90$ and $100^{\circ} \mathrm{C}$ and drying air velocity was at 4,5 and $6 \mathrm{~m} \mathrm{sec}^{-1}$. Drying Nomenclature $\mathrm{t}$ drying time $(\mathrm{min}) \mathrm{D}_{\text {eff }}$ coefficient of moisture diffusion $\left(\mathrm{m}^{2} \mathrm{sec}^{-1}\right) \mathrm{RC}$ radius of a cylindrical object (m) Rg fixed rate of gas MJ. $\mathrm{kg}$ mol. $\mathrm{K}^{-1}$ ) $\beta$ Bessel function's root at zero $T$ relative temperature $(K) . D_{o}$ initial constant number of moisture diffusion, $\left(\mathrm{m}^{2} \mathrm{sec}^{-1}\right)$ Ea activation of moisture diffusion $\left(\mathrm{MJkg} \mathrm{mol}^{-1}\right)$ was continued until chili were drifted or continuously moved from drying chamber. During the experiment ambient temperature, relative humidity, inlet or outlet temperatures of drying air in drying chamber were recorded.

Coefficient of moisture diffusion and activation energy: The solute or heat transport in a flat duct was defined by Johnson et al. (2008). Materials, paddy, seed of herbs were completely predicted by diffusion number in Fick's second law. Also it was used in 
calculating chili moisture coefficient at every temperature level in drying process according to the equation mentioned below:

$\mathrm{MR}=\frac{4}{\beta_{1}^{2}} \exp \left(\frac{-\beta_{1}^{2} \mathrm{D}_{\text {eff }}}{\mathrm{r}_{\mathrm{c}}^{2}} \mathrm{t}\right)$

Coefficient of chili's moisture diffusion was changed by the temperature more than the moisture, so it was developed the equation to solve the coefficient number of chili's moisture diffusion which was a type of Arrhenius's relation:

$\mathrm{D}_{\text {eff }}=\mathrm{D}_{0} \exp \left(\mathrm{E}_{\mathrm{a}} / \mathrm{R}_{\mathrm{g}} \mathrm{T}_{\mathrm{abs}}\right)$

$\ln D_{\text {eff }}=\ln D_{0}-\left(\mathrm{E}_{\mathrm{a}} / \mathrm{R}_{\mathrm{g}}\right)\left(1 / \mathrm{T}_{\mathrm{abs}}\right)$

It could obtain initial number of $\mathrm{D}_{0}$ and $\mathrm{E}_{\mathrm{a}}$ from the result correlation between $\ln \mathrm{D}_{0}$ and $\left(1 \mathrm{~T}_{\mathrm{abs}}\right)$ which was the equation of a straight line (Eq. 3), $\left(\mathrm{E}_{\mathrm{a}} / \mathrm{R}_{\mathrm{g}}\right)$ was the slope number of a graph.

\section{RESULTS}

Drying characteristics: The result of drying of capsicum based on continuous fluidized-bed dryer revealed that the drying time decreased from $27 \mathrm{~h}$ $\left(50^{\circ} \mathrm{C}\right.$ and $\left.4 \mathrm{~m} \mathrm{sec}^{-1}\right)$ to $2 \mathrm{~h} 25 \mathrm{~min}\left(100^{\circ} \mathrm{C}\right.$ and $6 \mathrm{~m}$ $\mathrm{sec}^{-1}$ ) when drying air temperature increased from 50, $60,70,80,90$ to $100^{\circ} \mathrm{C}$ and drying air velocity increased from 4-6 m sec${ }^{-1}$, respectively (Table 1). The change of moisture content of chili on wet basis from the experiment using the dryer machine (Fig. 1) showed that on drying air velocity of $4 \mathrm{~m} \mathrm{sec}^{-1}, 5 \mathrm{~m} \mathrm{sec}^{-1}$ and 6 $\mathrm{m} \mathrm{sec}^{-1}$, the chili's initial weight was $1000 \mathrm{~g}$ and final weight was $292.25 \mathrm{~g}$. Moreover, it contained the moisture content of $7.54 \%(\mathrm{wb})$ from experiment and $8.08 \%(\mathrm{wb})$ from central laboratory.

After the experiment( 1 month ago), 6 samples of dried chili on drying air velocity of $5 \mathrm{~m} \mathrm{sec}^{-1}$ were

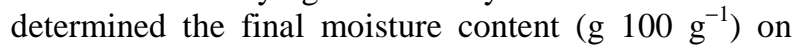
wet basis (Stephen and Emmanuel, 2009) and the compound capsaicin by HPLC based on AOAC (1995) 995.03 in house method. The capsaicin quantity of dried chili on drying air velocity of $5 \mathrm{~m} \mathrm{sec}^{-1}$ and drying temperature of $50,60,70,80,90$ and $100^{\circ} \mathrm{C}$

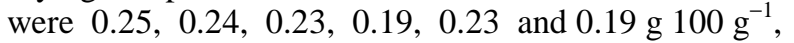

respectively. The capsaicin quantity of fresh chili on initial moisture content of $72.98 \%$ (wb) were $0.07 \mathrm{~g}$ $100 \mathrm{~g}^{-1}$. The result was certificated by Central Laboratory (Thailand) Ltd., Khon Kaen Branch: Nai Muang, Khon Kaen Thailand.

Diffusion coefficient and activation energy: Chili's diffusion coefficient would be changed by the temperature and drying air velocity of the drying process which stayed in a range of $1.3118 \mathrm{E}-09$ $1.3782 \mathrm{E}-08 \mathrm{~m}^{2} \mathrm{sec}^{-1}, 1.3330 \mathrm{E}-09-1.5197 \mathrm{E}-08 \mathrm{~m}^{2} \mathrm{sec}^{-1}$ and $8.4181 \mathrm{E}-010-1.0740 \mathrm{E}-08 \mathrm{~m}^{2} \mathrm{sec}^{-1}$. The effective moisture diffusivity of $50,60,70,80,90$ and $100^{\circ} \mathrm{C}$ and drying air velocity of $4-6 \mathrm{~m} \mathrm{sec}^{-1}$ can be written as following equations:

$D_{\text {eff }}=0.34749 \exp \left(-6237.24985 / T_{\text {abs }}\right)$

$\mathrm{D}_{\text {eff }}$ abs $\mathrm{D}=0.14262 \exp (-5981.47279 / \mathrm{T})$

$\mathrm{D}_{\text {eff }}=0.424045 \exp \left(-6439.97646 / \mathrm{T}_{\mathrm{abs}}\right)$

\section{DISCUSSION}

The result shown in Table 1 found that moisture content of dried chili (central laboratory) was higher as it was compared to the experimental result.

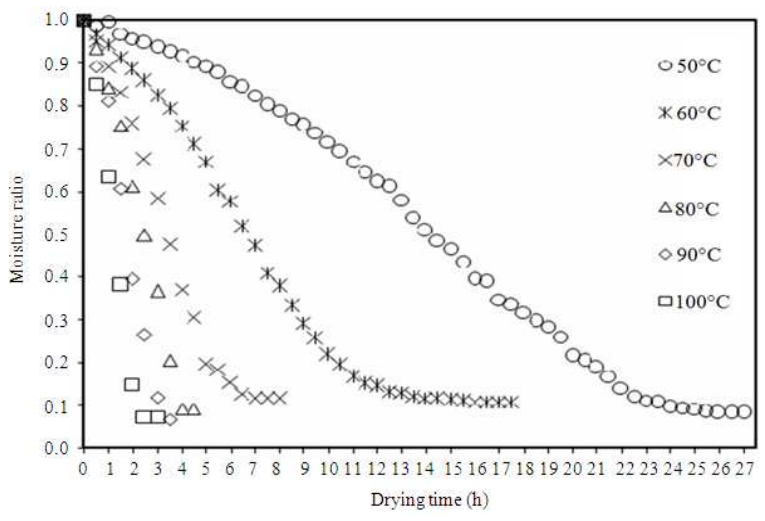

Fig. 2: Change of Moisture Ratio (MR) with drying time (h) on drying air velocity of $4 \mathrm{~m} \mathrm{sec}^{-1}$

Table 1: The results from the experiment and central laboratory (Thailand) Ltd., Khon Kaen branch

\begin{tabular}{|c|c|c|c|c|c|c|c|c|}
\hline \multirow{2}{*}{$\begin{array}{l}\text { Drying } \\
\text { temperature }\left({ }^{\circ} \mathrm{C}\right)\end{array}$} & \multicolumn{3}{|c|}{ Moisture content (\% wb) } & \multirow{2}{*}{$\begin{array}{l}\text { Moisture } \\
\text { content }\end{array}$} & \multirow{2}{*}{$\begin{array}{l}\text { Compound } \\
\text { capsaicin }\end{array}$} & \multicolumn{3}{|c|}{ Drying time (h) } \\
\hline & $4 \mathrm{~m} \mathrm{sec}^{-1}$ & $5 \mathrm{~m} \mathrm{sec}^{-1}$ & $6 \mathrm{~m} \mathrm{sec}^{-1}$ & & & $4 \mathrm{~m} \mathrm{sec}^{-1}$ & $5 \mathrm{~m} \mathrm{sec}^{-1}$ & $6 \mathrm{~m} \mathrm{sec}^{-1}$ \\
\hline 50 & 8.19 & 7.79 & 14.72 & $9.40 *$ & $0.25 * *$ & 27.00 & 26.00 & 22.50 \\
\hline 60 & 9.96 & 9.24 & 13.37 & $10.67 *$ & $0.24 * *$ & 17.50 & 14.00 & 13.00 \\
\hline 70 & 10.47 & 6.53 & 11.82 & $6.71 *$ & $0.25 * *$ & 8.00 & 5.00 & 5.00 \\
\hline 80 & 8.90 & 8.17 & 16.63 & $9.12 *$ & $0.19 * *$ & 4.50 & 3.75 & 3.25 \\
\hline 90 & 7.14 & 7.54 & 16.78 & $8.08 *$ & $0.23 * *$ & 3.75 & 3.00 & 2.75 \\
\hline 100 & 7.45 & 7.14 & 12.19 & $7.88^{*}$ & $0.19^{* *}$ & 3.00 & 2.75 & 2.25 \\
\hline
\end{tabular}

*: Stephen and Emmanuel (2009); **: Testing by HPLC based on AOAC (1995) 995.03 in house method 
Consequently, the decrease of moisture content affected the increase of capsaicin quantity of dried chili compared to fresh chili. The experimental result showed drying time decreased with the increasing of drying temperature and drying air velocity shown in Fig. 2-4. It also found that the suitable condition for drying process was $90^{\circ} \mathrm{C}$ of drying chamber's temperature and the drying air velocity at $5 \mathrm{~m} \mathrm{sec}^{-1}$.

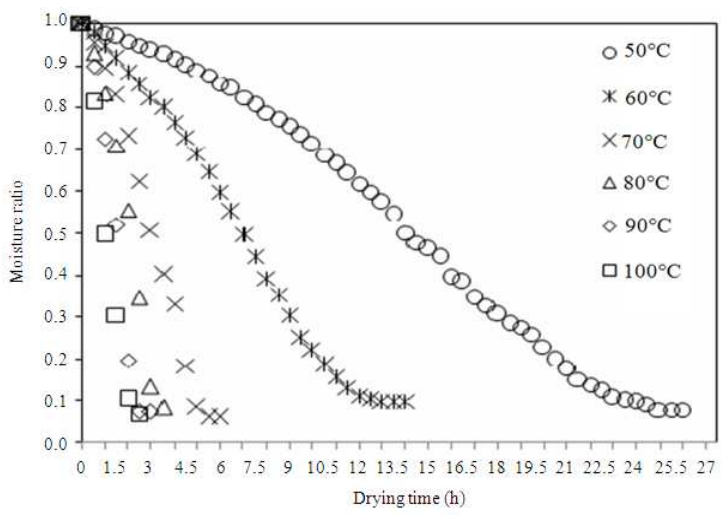

Fig. 3: Change of Moisture Ratio (MR) with drying time (h) on drying air velocity of $5 \mathrm{~m} \mathrm{sec}^{-1}$

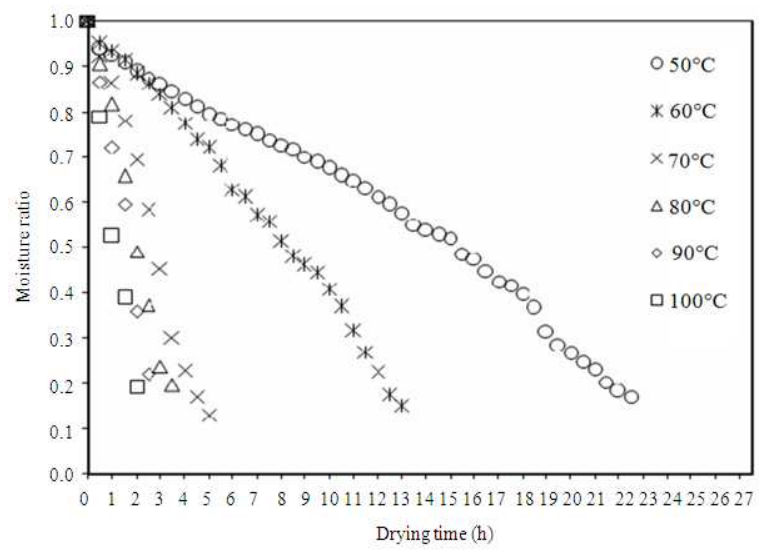

Fig. 4: Change of Moisture Ratio (MR) with drying time (h) on drying air velocity of $6 \mathrm{~m} \mathrm{sec}^{-1}$

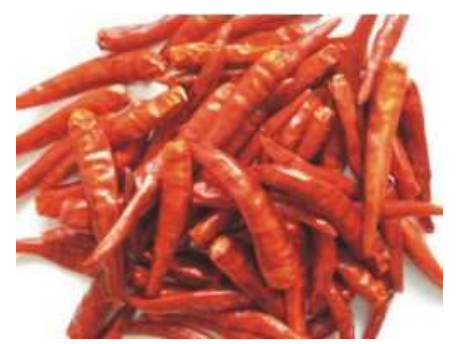

Fig. 5: Photograph of dried chili on the temperature of $90{ }^{\circ} \mathrm{C}$ and drying air velocity of $5 \mathrm{~m} \mathrm{sec}^{-1}$
In addition, with the duration of $3 \mathrm{~h}$, the chili's physical characteristics would turn into red, flat and shiny, crispy and no burning smell-showed in Fig. 5. It was found that the drying temperature affected the decrease of chili's weight and moisture content. The drying air velocity affected on the fluidized bed particles movement and the chili's continuous migration outwards the drying chamber.

The activation energy could be described based on Eq. 3. The Fig. 6 showed the increasing of the effective moisture diffusivity when drying temperature and drying air velocity increased. The result of the correlation graph between $\left(\ln _{\text {eff }}\right)$ and $\left(1 / T_{\text {abs }}\right)$ as shown in Fig. 7-9, the time (h) on drying air velocity of $5 \mathrm{~m} \mathrm{sec}^{-1}$ obtained activation energy of diffusion Ea.

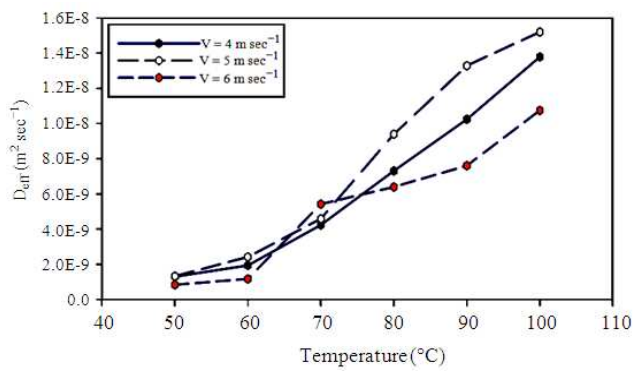

Fig. 6: The effective moisture diffusivity on drying temperature of $50,60,70,80,90$ and $100^{\circ} \mathrm{C}$ and drying air velocity of 4,5 and $6 \mathrm{~m} \mathrm{sec}^{-1}$

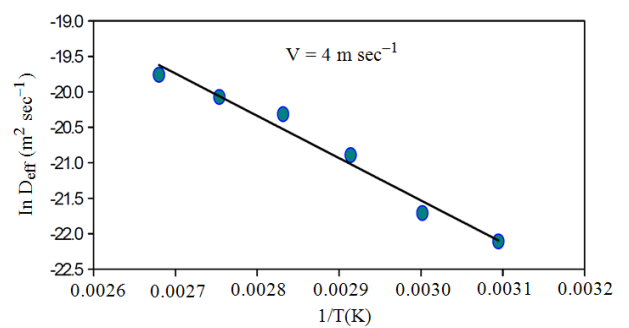

Fig. 7: The Arrhenius relationship between the effective diffusivities and temperature on drying air velocity of $4 \mathrm{~m} \mathrm{sec}^{-1}$

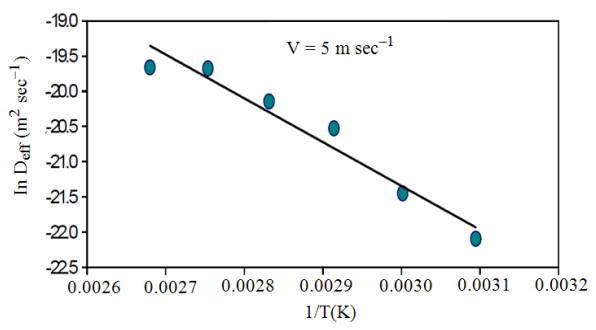

Fig. 8: The Arrhenius relationship between the effective diffusivities and temperature on drying air velocity of $5 \mathrm{~m} \mathrm{sec}^{-1}$ 


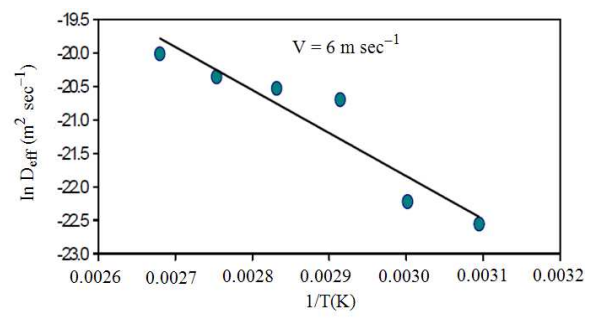

Fig. 9: The Arrhenius relationship between the effective diffusivities and temperature on drying air velocity of $6 \mathrm{~m} \mathrm{sec}^{-1}$

This was calculated as $49.7299,51.8564$ and 53.5419 MJkg mol ${ }^{-1}$ on 4-6 m sec-1 of drying air velocity, respectively. Thus, the air velocity affected the change of chili's activation energy.

\section{CONCLUSION}

Drying temperature was the significant factor of the chili moisture content reduction and the increase of capsaicin quantity substance of dried chili compared to fresh chili. The drying air velocity affected the move of chili particles. Drying was continued until chili were drifted or continuously moved from drying chamber under continuous fluidized-bed drying process. The suitable condition result of this study was drying temperature of $90^{\circ} \mathrm{C}$, drying air velocity of $5 \mathrm{~m} \mathrm{sec}^{-1}$ and drying time of $3 \mathrm{~h}$ because of the best physical characteristic of dried chili, high compound capsaicin and the shorten drying time. Consequently, the increase of drying air temperature and drying air velocity affected on the increase of the effective moisture diffusivity.

\section{ACKNOWLEDGEMENT}

The researchers are grateful to the support given by Department of Mechanical Engineering, Faculty of Engineering, Khon Kaen University and Department of Mechanical Engineering, Faculty of Engineering Rajamangala University of Technology, Khon Kaen Campus.

\section{RERERENCES}

AOAC, 1995. AOAC official method 995.03 capsaicinoids in capsicums and their extractives, liquid chromatographic method. AOAC. http://www.pinkstinker.com/docs/AOAC_Official_ Method_995.pdf

Cisneros-Pineda, O., L.W. Torres-Tapia, L.C. GutiérrezPacheco, F. Contreras-Martín and T. GonzálezEstrada et al., 2007. Capsaicinoids quantification in chili peppers cultivated in the state of Yocatan, Mexico. Food Chem., 104: 1755-1760. DOI: 10.1016/j.foodchem.2006.10.076
De, A.K., 2003. Capsicum: The Genus Capsicum. 1st Edn., CRC Press, New York, ISBN: 10: 0415299918, pp: 296.

Haddad, J.S., 2009. Basic theoretical backgrounds of the engineering design procedure of a drying plant. Am. J. Eng. Applied Sci., 2: 466-470. http://www.scipub.org/fulltext/ajeas/ajeas22466-470.pdf

Johnson, E., A.D. Apeti, S. Haynes and L. Robinson, 2008. Solute or heat transport in a flat duct. Am. J. Environ. $\quad$ Sci., $\quad 4$ 721-726. http://www.scipub.org/fulltext/ajes/ajes46721-726.pdf

Kaleemullah, S. and R. Kailappan, 2005. Drying kinetics of red chillies in a rotary dryer. Biol. Eng., 92: 15-23. DOI: 10.1016/j.biosystemseng.2005.05.015

Laohavechvanich, P., K. Kangsadalampai, N. Tirawanchai and A.J. Ketterman, 2006. Effect of different Thai traditional processing of various hot chili peppers on urethane-induced somatic mutation and recombination in Droxophila melanogaster: Assessment of the role of glutathione transferase activity. Food Chem. Toxicol., 44: 1348-1354. DOI: $10.1016 /$ j.fct.2006.02.013

Luce, A., K. Mattas, I. Tzouramani, G. Paroussi and E. Tsakiridou et al., 2006. Financial assessment of a new soil heating technology for off-season asparagus production. Am. J. Agric. Biol. Sci., 1: 6-9.

http://www.scipub.org/fulltext/AJAB/AJAB116-9.pdf

Satyanarayana, CH.V.V. and P.C. Vengaiah, 2010. Development of large scale drying system for chilies (Capsicum annum). Agric. Eng. Int. GIGR J., 12: 189-193. http://www.cigrjournal.org/index.php/Ejounral/art icle/viewFile/1477/1290

Stephen, A.K. and S. Emmanuel, 2009. Improvement on the design of a cabinet grain dryer. Am. J. Eng. Applied $\quad$ Sci., $\quad 2$ 217-228. http://www.scipub.org/fulltext/ajeas/ajeas21217-228.pdf

Shafri, H.Z.M. and M.S. Ezzat, 2009. Quantitative performance of spectral indices in large scale plant health analysis. Am. J. Agric. Biol. Sci., 4: 187-191. http://www.scipub.org/fulltext/AJAB/AJAB43187191.pdf

Tasirin, S.M., S.K. Kamarudin, K. Jaafar and K.F. Lee, 2006. The drying kinetics of bird's chilies in a fluidized bed dryer. J. Food. Eng., 79: 695-705. DOI: $10.1016 /$ j.jfoodeng.2006.02.032 